\title{
Stable carbon isotope variability in the seagrass Posidonia oceanica: evidence for light intensity effects
}

\author{
Lee W. Cooper*, Michael J. DeNiro**
}

Department of Earth and Space Sciences, University of California, PO Box 241438, Los Angeles, California 90024-9238, USA

\begin{abstract}
Stable carbon isotope ratios were determined for leaves of the seagrass Posidonia oceanica (L.) Delile collected over a $38 \mathrm{~m}$ depth gradient at Bay of Calvi, Corsica. Although variability in $\delta^{13} \mathrm{C}$ values among individual leaves at specific depths was as high as $6 \%$, there was an overall trend towards less discrimination against ${ }^{13} \mathrm{C}$ at the shallowest water levels. The mean $\delta^{13} \mathrm{C}$ value of leaves at $5 \mathrm{~m}$ was $-11.0 \%$ and declined to a minimum mean of $-16.4 \%$ at $35 \mathrm{~m}$. Isotopic variability in individual leaves divided into thirds was consistent with this trend, except in those leaf sections nearest to the meristem, whose $\delta^{13} \mathrm{C}$ values did not vary with depth. A variety of explanations for these observations were considered, including the effects of light intensity, temperature, pressure, relative water motion, seasonal variability in biochemical fractionation, isotopic variability in the dissolved inorganic carbon pool, and differential use of bicarbonate and dissolved carbon dioxide on the carbon isotopic composition of $P$, oceanica. Differences in light intensity and consequently photosynthetic rate are most likely to influence discrimination against ${ }^{13} \mathrm{C}$ and thus account for the observations reported here.
\end{abstract}

\section{INTRODUCTION}

Seagrasses exhibit a wide range of ${ }^{13} \mathrm{C} /{ }^{12} \mathrm{C}$ ratios. The $\delta^{13} \mathrm{C}$ values ${ }^{* *}$ of 47 species range from -3.0 to $-23.8 \%$ (McMillan et al. 1980). Terrestrial plants show a similar span of $\delta^{13} \mathrm{C}$ values, ranging from -9 to $-33 \%$ (Deines 1980). The primary cause of carbon isotope variability in terrestrial plants is differential discrimination against ${ }^{13} \mathrm{CO}_{2}$ and ${ }^{12} \mathrm{CO}_{2}$ at the initial carboxylation step in photosynthesis. Thus, $\delta^{13} \mathrm{C}$ values can distinguish terrestrial plants utilizing the $\mathrm{C}_{3}$ and $\mathrm{C}_{4}$ pathways (Bender 1971, Smith \& Epstein 1971) because the 2 enzymes involved in fixing atmospheric $\mathrm{CO}_{2}$, ribulose bisphosphate carboxylase and phosphoenol pyruvate carboxylase, fractionate carbon isotopes differently (O'Leary 1981).

- Present address: Environmental Sciences Division, Oak Ridge National Laboratory, Oak Ridge, Tennessee 37831 , USA, and Department of Geological Sciences, University of Tennessee, Knoxville, Tennessee 37996, USA

* Present address: Department of Geological Sciences, University of California, Santa Barbara, California 93106, USA

$\cdots \delta{ }^{13} \mathrm{C}=\left[\left(\mathrm{R}_{\text {sample }} / \mathrm{R}_{\mathrm{PDB}}\right)-1\right] \times 1000 \%$; $\mathrm{R}={ }^{13} \mathrm{C} /{ }^{12} \mathrm{C}$; PDB is standard from the Peedee Formation, South Carolina, given an arbitrary $\delta^{13} \mathrm{C}$ value of $0.0 \%$
Differences in enzymatic discrimination do not explain carbon isotope variability in submerged aquatic plants (O'Leary 1981, Sternberg et al. 1984, Keely et al. 1986). The causes of variability in the carbon isotopic composition of seagrasses and other submerged aquatic plants have been attributed to a wide variety of other causes. Increased water motion can enhance diffusion of inorganic carbon and increase the influence of enzymatic discriminations (Osmond et al. 1981, Raven et al. 1982). Seasonal variability in isotopic fractionations associated with biochemical processes has been implicated in marine macrophytes (Thayer et al. 1978, Stephenson et al. 1984, Simenstad \& Wissmar 1985). Isotopic variability in the dissolved inorganic carbon pool will influence $\delta^{13} \mathrm{C}$ values, particularly in estuarine and freshwater macrophytes (Smith et al. 1976, McMillan et al. 1980, Osmond et al. 1981, McMillan \& Smith 1982). Lower temperatures increase fractionations among dissolved inorganic carbon species in seawater, so in colder water more negative $\delta^{13} \mathrm{C}$ values can be expected (Degens et al. 1968, Wong \& Sackett 1978). Differential use of bicarbonate and dissolved carbon dioxide, which are isotopically distinct, could alter $\delta^{13} \mathrm{C}$ values of aquatic plants (Andrews \& Abel 1977, Benedict et al. 1980, Faganeli et al. 1986). Recently, it has been reported that $\delta^{13} \mathrm{C}$ 
values in the green alga Halimeda incrassata are influenced by light intensity (Wefer \& Killingley 1986). We report here evidence that light intensity also apparently affects carbon isotope discrimination in the seagrass Posidonia oceanica (L.) Delile.

Posidonia oceanica is a dominant endemic seagrass in the Mediterranean Sea, forming large submerged beds and growing to depths as great as $40 \mathrm{~m}$ (Den Hartog 1970). We took advantage of the plant's capacity to grow under comparatively low as well as high light conditions over a depth gradient to study the influence of light on isotopic variability. Growth dynamics and productivity of plants and such physical factors as water temperature and light irradiance have been extensively studied at the site chosen for the investigation (Bay 1984).

\section{METHODS}

Leaves of Posidonia oceanica were collected at $5 \mathrm{~m}$ intervals from 5 to $38 \mathrm{~m}$ water depth in Calvi Bay, Corsica, on 7 August 1987. At each depth at least 3 separate leaves from 3 separate shoots were collected. The leaves selected were the youngest leaves on each shoot that were at least $10 \mathrm{~cm}$ long. This criterion was used to minimize the possibility of isotopic variability due to different leaf ages. The leaves were at most lightly epiphytized, and any visible epiphytes were removed by hand. For each depth, one of these 3 leaves was further divided into thirds. Each of the 3 leaf sections were analyzed separately to characterize the degree of intra-leaf isotopic variation.

Samples were air dried, followed by freeze drying. Of the homogenized leaves, $5 \mathrm{mg}$ portions were combusted in the presence of copper oxide, copper and silver foil at $875^{\circ} \mathrm{C}$ in vacuum sealed quartz glass tubes. Carbon dioxide generated was purified cryogenically and analyzed mass spectrometrically by simultaneous comparison with a known standard. An internal standard consisting of Posidonia oceanica leaf material was also analyzed 6 times; standard deviation for all analytical errors and errors of preparation was $\pm 0.2 \%$. For statistical analyses, a normal distribution was assumed for samples collected at each depth. Regression equations were calculated for Type I relationships between individual water depths (independent variable) and $\delta^{13} \mathrm{C}$ values (dependent variable).

\section{RESULTS}

$\delta^{13} \mathrm{C}$ values of whole Posidonia oceanica leaves decreased from a maximum mean of $-11.0 \%$ at $5 \mathrm{~m}$ to a minimum mean of $-16.4 \%$ at $35 \mathrm{~m}$ water depth (Fig. 1). Despite high variability at certain depths, there

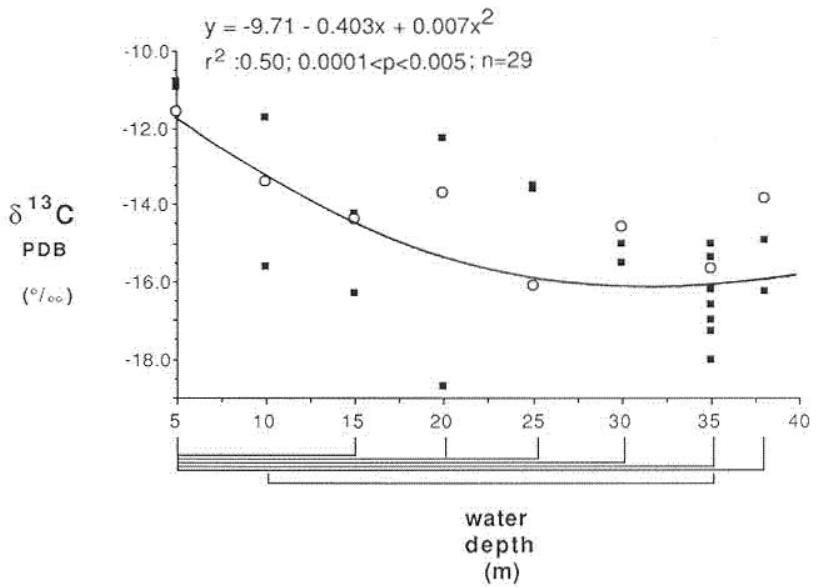

Fig. 1. Posidonia oceanica. Stable carbon isotope ratios of individual whole leaves, Bay of Calvi, Corsica (\$). o: weight averaged composite samples made up of 3 leaf segments analyzed separately and plotted on Fig. 2; whole leaf carbon isotope ratios of these leaves were estimated by multiplying individual segment $\delta^{13} \mathrm{C}$ value by the proportional contribution of each segment to total leaf weight and integrating for the whole leaf. Regression line and statistical analyses correspond to both composite and whole leaf samples. Lines connecting depths along abscissa indicate significant $(p<0.05)$ differences between mean carbon isotope ratios (StudentNewman-Keuls Test)

was a significant correlation $(0.0001<p<0.005)$ between water depth and whole leaf $\delta^{13} \mathrm{C}$ value (Fig. 1; $\left.\delta^{13} C=-9.71-0.403 x+0.007 x^{2}\right)$. The shift in carbon isotope ratios was greatest immediately below $5 \mathrm{~m}$ depth, indicating a non-linear relationship. These indications of non-linearity were supported by a comparison of mean $\delta^{13} \mathrm{C}$ values at each depth using a Student-NewmanKeuls Test (Sokal \& Rohlf 1981). The mean $\delta^{13} \mathrm{C}$ value observed at $5 \mathrm{~m}$ was significantly different $(p<0.05)$ from that observed at all other depths except $10 \mathrm{~m}$. Differences among all other depths were not significantly different except between $10 \mathrm{~m}$ and $35 \mathrm{~m}$ (Fig. 1). Nevertheless, even with the data collected at $5 \mathrm{~m}$ excluded, there remained a significant correlation between depth and decreasing $\delta^{13} \mathrm{C}$ value $(r=-0.41 ; 0.025<p<0.05)$.

For leaves divided into thirds, there was a significant correlation $(0.005<p<0.01)$ for the fraction nearest to the tip of the leaf blade (Fig. $2 ; \delta^{13} \mathrm{C}=-7.928-0.471 \mathrm{x}$ $\left.+0.008 \mathrm{x}^{2}\right)$. Variability in the $\delta^{13} \mathrm{C}$ values of the middle portion of the leaf was related to water depth (Fig. $2 ; \delta^{13} \mathrm{C}$ $\left.=-9.996-0.449 \mathrm{x}+0.008 \mathrm{x}^{2}\right)$, although not as strongly $(0.01<p<0.025) . \delta^{13} \mathrm{C}$ values of the portion of the leaf closest to the meristem were not related to depth (Fig. 2).

\section{DISCUSSION}

The correlation between depth and $\delta^{13} \mathrm{C}$ values is probably a light intensity effect, because it is unlikely 


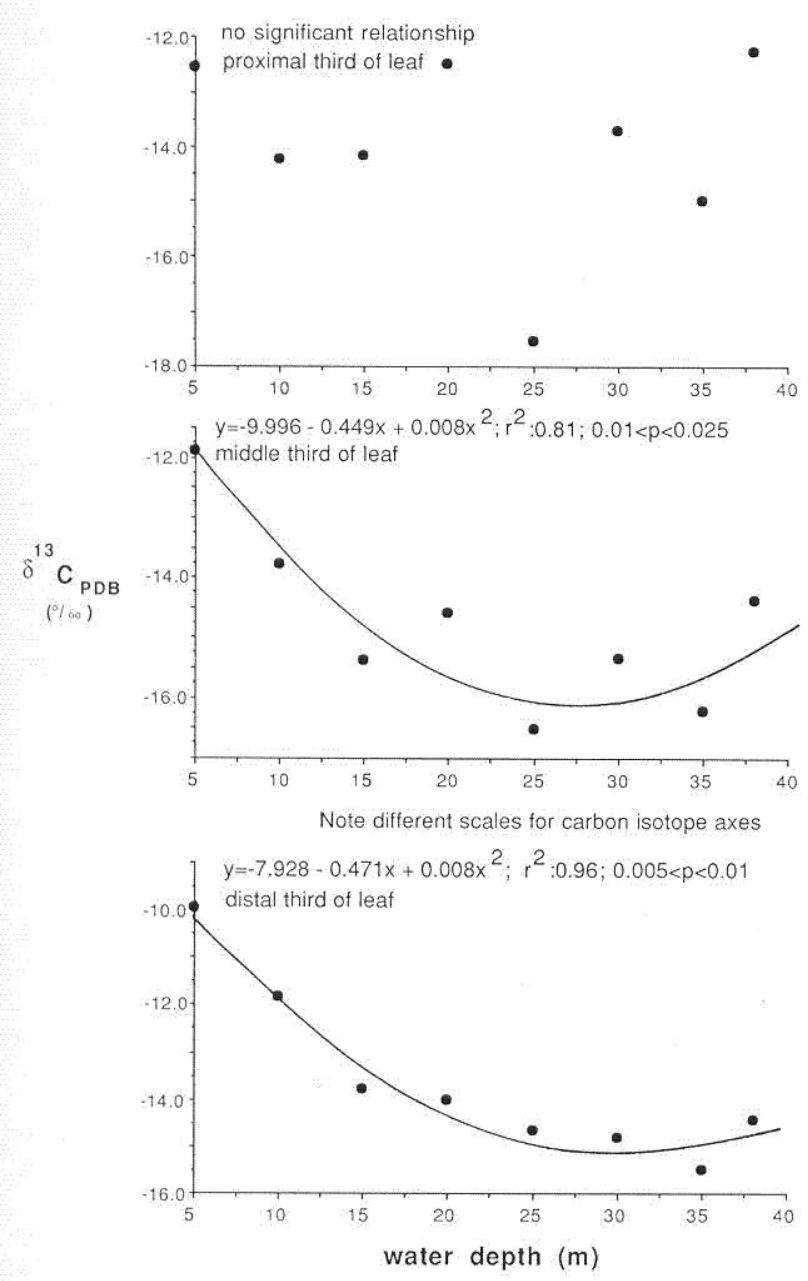

Fig. 2. Posidonia oceanica. Stable carbon isotope ratios of individual leaf segments divided in thirds; 1st third of leaf is that closest to meristem; 3rd third is at tip of each leaf

that any other environmental factor would influence the $\delta^{13} \mathrm{C}$ values of the leaf tips and not those of portions of the leaf closest to the meristem. The difference in $\delta^{13} \mathrm{C}$ values is greatest between 5 and $10 \mathrm{~m}$. This is consistent with summer irradiance patterns at this site, which decline to $30 \%$ of surface irradiance at $10 \mathrm{~m}$ (Bay 1984). The complete lack of depth-related $\delta^{13} \mathrm{C}$ variability in the portion of the leaf closest to the meristem is consistent with an irradiance effect because those portions of leaves are most affected by canopy shading.

Other possible explanations for carbon isotope variability in submerged aquatic plants include water temperature differences between the surface and bottom, relative water motion, biochemical fractionation associated with seasonal variability, isotopic variability in the dissolved inorganic carbon pool, and differential use of bicarbonate and dissolved carbon dioxide.

It is possible that isotopic variability could be driven partly by temperature differences between the surface and bottom of the depth gradient affecting both enzy- matic discrimination and the isotopic composition of the dissolved inorganic carbon (DIC) pool. Temperature differences in enzymatic discrimination, with up to a $2 \%$ decline in $\delta^{13} \mathrm{C}$ values with increasing temperature, have been reported (O'Leary 1981). In our study, plants in warmer surface waters had $\delta^{13} \mathrm{C}$ values less negative than those in colder deep waters, so we conclude that changes in enzymatic discrimination due to temperature variation are not significant. The largest temperature difference Bay (1984) observed at the study site between 10 and $38 \mathrm{~m}$ occurred when it was $25^{\circ} \mathrm{C}$ at $10 \mathrm{~m}$ and $15^{\circ} \mathrm{C}$ at $30 \mathrm{~m}$. Under these conditions, the difference between $\delta^{13} \mathrm{C}$ values of dissolved $\mathrm{CO}_{2}$ with respect to that of dissolved $\mathrm{HCO}_{3}{ }^{-}$declines from $-10.1 \%$ at $15^{\circ} \mathrm{C}$ to $-9.0 \%$ at $25^{\circ} \mathrm{C}$. The difference between $\delta^{13} \mathrm{C}$ values of dissolved $\mathrm{HCO}_{3}{ }^{-}$with respect to gaseous $\mathrm{CO}_{2}$ also declines, from -7.9 to $-9.0 \%$ over the same temperature range (Mook et al. 1974). Thus at $15^{\circ} \mathrm{C}$, DIC available for photosynthesis is slightly more depleted in ${ }^{13} \mathrm{C}$ than that near the surface. A $10^{\circ} \mathrm{C}$ difference would cause a change of $1 \%$ in the $\delta^{13} \mathrm{C}$ values of DIC, so, at most, could account for only onefifth of the $5 \%$ variation we observed in the $\delta^{13} \mathrm{C}$ values of Posidonia oceanica leaf material. Since for most of the year, temperature differences between 10 and $30 \mathrm{~m}$ are much smaller than $10^{\circ} \mathrm{C}$ (Bay 1984), temperature is unlikely to account even for this small change.

Evidence in freshwater plants for water motion effects on carbon isotope variability is not supported by a study of the seagrasses Phyllospadix serrulatus and Phyllospadix torreyi (Cooper \& McRoy in press), which are subjected to much greater extremes in water motion than Posidonia oceanica.

Seasonal variability in isotope effects associated with biochemical processes was minimized by consistently sampling the last leaf initiated that was at least $10 \mathrm{~cm}$ long. Analysis of horizontal rhizome leaf scars indicate that Posidonia oceanica at this site produces ca 10 new leaves per year per rhizome (own unpubl. data), which is consistent with other populations (Pergent et al. 1983, Mossé 1984). Furthermore, new leaf production rates in Bay of Calvi are highest in August (Bay 1984), so it is reasonable to assume that all leaves collected were of approximately the same age.

Isotopic variability in oceanic DIC pools is not significant except in estuaries (Fry \& Sherr 1984). The study site has no significant freshwater input at any time during the year. $\mathrm{CO}_{2}$ chemistry in the water above the Bay of Calvi Posidonia oceanica bed has been extensively studied (Frankignoulle \& Distèche 1984, 1987). Typical diel and seasonal differences between surface water and water amongst seagrasses growing at $8 \mathrm{~m}$ are on the order of $0.1 \mathrm{pH}$ units. In another study of seasonal changes in DIC in St. Margaret's Bay, Nova Scotia, where the seagrass Zostera marina grows under 
shallower conditions with presumably greater freshwater input, seasonal differences in DIC $\delta^{13} \mathrm{C}$ values ranged from +0.6 to $+1.3 \%$ (Stephenson et al. 1984). Thus we conclude that it is unlikely that relatively small potential variations in DIC over the depth gradient could account for the range of $\delta^{13} \mathrm{C}$ values observed.

Differential use of dissolved bicarbonate and carbon dioxide is a possibility, but would necessitate that plants in the surface water use bicarbonate while deeper water plants would depend more on dissolved carbon dioxide, a scenario for which there is no other evidence.

Having disposed of the aforementioned competing explanations, we conclude that changes in light intensity over the depth gradient are responsible for the patterns observed in $\delta^{13} \mathrm{C}$ values of Posidonia oceanica leaf material reported here. In the marine environment, similar patterns of ${ }^{13} \mathrm{C}$ depletion with depth have been observed in the green alga Halimeda incrassata (Wefer \& Killingley 1986) and zooxanthellae of coral (Muscatine et al. in press). Wefer \& Killingley (1986) observed the same pattern that $P$. oceanica showed: the largest change in $\delta^{13} \mathrm{C}$ values occurred moving from the surface to $10 \mathrm{~m}$ depth with smaller additional changes once this threshold had been passed. The general pattern of ${ }^{13} \mathrm{C}$ depletion with depth is consistent with the hypothesis that at higher light intensities, higher photosynthetic rates result in less discrimination against ${ }^{13} \mathrm{C}$. In marine plants growing under high light intensities, high photosynthetic rates will increase the influence of diffusion-dependent processes in inorganic carbon acquisition. These rate-limiting, diffusion-dependent processes would increase the use of ${ }^{13} \mathrm{C}$ that would otherwise be discriminated against.

Increasing light intensity in terrestrial plants can also alter discrimination against ${ }^{13} \mathrm{C}$, although shifts in $\delta^{13} \mathrm{C}$ values toward both more positive and more negative values have been observed (O'Leary 1981), possibly because of the influence of water relations and stomatal behavior on $\delta^{13} \mathrm{C}$ values (Farquhar et al. 1982). Nevertheless, it is possible that this light intensity pattern is present in tree canopies, where negative shifts close to the ground have been attributed primarily to photosynthetic fixation of ${ }^{13} \mathrm{C}$-depleted $\mathrm{CO}_{2}$ produced from decomposition of leaf litter and by plant respiration (Medina \& Minchin 1980, Schleser \& Jayasekera 1985).

Light intensity effects may be important for the application of carbon isotope measurements in food web studies (Fry \& Sherr 1984). Unless plants are collected from all depths at which they grow, characterization of marine plant $\delta^{13} \mathrm{C}$ values from analysis of more easily collected shallow samples may understate the degree of discrimination against ${ }^{13} \mathrm{C}$ in plants growing in sub- dued light. As an example, previous studies reported $\delta^{13} \mathrm{C}$ values for Posidonia oceanica that are considerably more positive than the deeper water plants in this study (Bricout et al. 1980, McMillan et al. 1980). Use of these data to characterize the $\delta^{13} \mathrm{C}$ values of the food of an herbivore feeding on $P$. oceanica would lead to substantial errors in dietary reconstruction if the animal was feeding at deeper depths.

Acknowledgements. We thank H. Kirkman for collecting the samples. V. Demoulin, D. Bay, Ch.-F. Boudouresque, and the staff of STARESO, Station de recherches sous-marines et océanographiques de l'Université de Liège, provided logisti$\mathrm{cal}$ assistance and facilitated the visit of the first author to the research site. J. Grebmeier provided assistance in the field and $\mathrm{D}$. Winter performed the mass spectrometric determinations. Three anonymous reviewers provided constructive comments. Supported by NSF grant DMB 84-05003 and by DOE grant DE-87ER60615.

\section{LITERATURE CITED}

Andrews, T. J., Abel, K. M. (1977). Photosynthetic carbon metabolism in seagrasses. ${ }^{14} \mathrm{C}$ labelling evidence for the $\mathrm{C}_{3}$ pathway. Plant Physiol. 63: 650-656

Bay, D. (1984). A field study of the growth dynamics and productivity of Posidonia oceanica (L.) Delile in Calvi Bay, Corsica. Aquat. Bot. 20: 43-64

Bender, M. M. (1971). Variations in the ${ }^{13} \mathrm{C} /{ }^{12} \mathrm{C}$ ratios of plants in relation to the pathway of photosynthetic carbon dioxide fixation. Phytochem. 10: 1239-1244

Benedict, C. R., Wong, W. W. L., Wong, J. H. H. (1980). Fractionation of the stable isotopes of inorganic carbon by seagrasses. Plant Physiol. 65: 512-517

Bricout, J., Boudouresque, C.-F., Giraud, G., Panayotidis, P. (1980). Le rapport ${ }^{13} \mathrm{C} /{ }^{12} \mathrm{C}$ chez Posidonia oceanica et Cymodocea nodosa. Trav. sci. Parc nation. Port-Cros, Fr. 6: 289-292, Notes brèves

Cooper, L. W., McRoy, C. P. (in press). Stable carbon isotope ratio variations in marine macrophytes along intertidal gradients. Oecologia (Berl.)

Degens, E. T., Guillard, R. R. L., Sackett, W. M., Hellebust, J. A. (1968). Metabolic fractionation of carbon isotopes in marine plankton. I. Temperature and respiration experiments. Deep Sea Res. 15: 1-10

Den Hartog, C. (1970). The Seagrasses of the World. NorthHolland, Amsterdam

Deines, P. (1980). The isotopic composition of reduced organic carbon. In: Fritz, P., Fontes, J. Ch. (eds.) Handbook of environmental isotope geochemistry. Vol. 1, Chap. 9. Elsevier, Amsterdam, p. 329-406

Faganeli, J., Vukovic, A., Saleh, F. I., Pezdic, J. (1986). C:N:P ratios and stable carbon and hydrogen isotopes in the benthic marine algae, Ulva rigica C. Ag. and Fucus virsoides J. Ag. J. exp. mar. Biol. Ecol. 102: 153-166

Farquhar, G. D., O'Leary, M. H., Berry, J. A. (1982). On the relationship between carbon isotope discrimination and the intercellular carbon dioxide concentration in leaves. Aust. J. Plant Physiol. 9: 121-137

Frankignoulle, M., Distèche, A. (1984). $\mathrm{CO}_{2}$ chemistry in the water column above a Posidonia seagrass bed and related air-sea exchanges. Oceanol. Acta 7 (2): 209-219 
Frankignoulle, M., Distèche, A. (1987). Study of the transmission of the diurnal $\mathrm{CO}_{2}$ concentration changes observed above a Posidonia seagrass bed: a method to determine the turbulent diffusion coefficient in an $8-\mathrm{m}$ water column. Cont. Shelf Res. 7: 67-76

Fry, B., Sherr, E. B. (1984), $\delta^{13} \mathrm{C}$ measurements as indicators of carbon flow in marine and freshwater ecosystems. Contrib. mar. Sci. 27: 13-47

Keely, J. E., Sternberg, L. O., DeNiro, M. J. (1986). The use of stable isotopes in the study of photosynthesis in freshwater plants. Aquat. Bot. 26: 213-223

McMillan, C., Parker, P. L., Fry, B. (1980). ${ }^{13} \mathrm{C} /{ }^{12} \mathrm{C}$ ratios in seagrasses. Aquat. Bot. 9: 237-249

McMillan, C., Smith, B. N. (1982). Comparison of $\delta^{13} \mathrm{C}$ values for seagrasses in experimental cultures and in natural habitats. Aquat. Bot. 14: 381-387

Medina, E., Minchin, P. (1980). Stratification of $\delta^{13} \mathrm{C}$ values of leaves in Amazonian rain forests. Oecologia (Berl.) 45: $377-378$

Mook, W. G., Bommerson, J. C., Staverman, W. H. (1974). Carbon isotope fractionation between dissolved bicarbonate and gaseous carbon dioxide. Earth Planet. Sci. Lett. 22: $169-176$

Mossé, R.-A. (1984). Recherches lépidochronologiques sur Posidonia oceanica: Rhizomes plagiotropes et orthotropes des herbiers profonds de Port-Cros (Méditerranée, France). Trav. sci. Parc. nation. Port-Cros, Fr. 10: 87-107

Muscatine, L., Porter, J. W., Kaplan, I. R. (in press). Resource partitioning by reef corals as determined from stable carbon isotope composition. I. $\delta^{13} \mathrm{C}$ of zooxanthellae and animal tissue vs, depth. Mar. Biol.

O'Leary, M. H. (1981). Carbon isotope fractionation in plants. Phytochem. 20: 553-567

Osmond, C. B., Valaane, N., Haslam, S. M., Votila, P., Roksandic, Z. (1981). Comparison of $\delta^{13} \mathrm{C}$ values in leaves of aquatic macrophytes from different habitats in Britain and Finland: some implications for photosynthetic processes in aquatic plants. Oecologia (Berl.) 50: 117-124

Pergent, G., Boudoureseque, C.-F., Crouzet, A. (1983). Varia- tions cycliques dans les écailles des rhizones orthotropes de Posidonia oceanica. Trav. sci. Parc nation. Port Cros, Fr. 9: 107-148

Raven, J. A., Beardall, J., Griffiths, H. (1982). Inorganic Csources for Lemanea, Cladophora and Ranunculus in a fast-flowing stream: Measurements of gas exchange and of carbon isotope ratios and their ecological implications. Oecologia (Berl.) 53: 68-78

Schleser, G. H., Jayasekera, R. (1985). $\delta^{13} \mathrm{C}$ variations of leaves in forests as an indication of reassimilated $\mathrm{CO}_{2}$ from the soil. Oecologia (Berl.) 65: 536-542

Simenstad, C. A., Wissmar, R. C. (1985). ${ }^{13}$ C evidence of the origins and fates of organic carbon in estuarine and nearshore food webs. Mar. Ecol. Prog. Ser. 22: 141-152

Smith, B. N., Oliver, J., McMillan, C. (1976). Influence of carbon source, oxygen concentration, light intensity and temperature on ${ }^{13} \mathrm{C} /{ }^{12} \mathrm{C}$ ratios. Bot. Gaz. 137: 99-104

Smith, B. N., Epstein, S. (1971). Two categories of ${ }^{13} \mathrm{C} /{ }^{12} \mathrm{C}$ ratios for higher plants. Plant Physiol. 47: 380-384

Sokal, R. R., Rohlf, F. J. (1981). Biometry, 2nd edn. W. H. Freeman, San Francisco

Stephenson, R. L., Tan, F. C., Mann, K. H. (1984). Stable carbon isotope variability in marine macrophytes and its implications for food web studies. Mar. Biol. 81: 223-230

Stermberg, L., DeNiro, M. J., Keely, J. E. (1984). Hydrogen, oxygen and carbon isotope ratios of cellulose from submerged aquatic crassulacean acid metabolism and noncrassulacean acid metabolism plants. Plant Physiol. 76: $68-70$

Thayer, G. W., Parker, P. L., Lacroix, M. W., Fry, B. (1978). The stable carbon isotope ratio of some components of an eelgrass, Zostera marina, bed. Oecologia (Berl.) 35: 1-12

Wefer, G., Killingley, J. S. (1986). Carbon isotopes in organic matter from a benthic alga Halimeda incrassata (Bermuda): effects of light intensity. Chem. Geol. (Isotope Geosciences Section) 59: 321-326

Wong, W. W., Sackett, W. M. (1978). Fractionation of stable isotopes by marine phytoplankton. Geochim. cosmochim. Acta 42: 1809-1815 